\title{
Techniques and Materials Used in the Construction of the Mosques in the Dobrogea Area
}

\author{
Sever Suliman and Ana Maria Grămescu
}

\begin{abstract}
In this paper the authors show the investigations importance on the constituent materials of the mosques, to understand their behaviour in the environment actions, but also for the using off efficient intervention measures. In this paper a comparative analysis is made between three mosques on the territory of Dobrogea, which were built in different periods, and located in areas with different location characteristics.
\end{abstract}

Keywords - comparative analysis, mosque, rehabilitation

\section{INTRODUCTION}

In this paper, the authors purpose to study the type of materials and technologies specific to the last 500 years, in terms of the building types of Muslim worship places in Romania, especially in the Dobrogea area, more exactly the buildings that are classified as historical monuments. Globally, these constructions are preserved through repair, restoration and consolidation works carried out by specialists, which demonstrates the existence of special concerns of specialists for the preservation of heritage, cultural and spiritual values through specific techniques and methods.

The mosques on the Dobrogea area, which are presented in this study, have a special importance and history. These buildings are made up of two important elements: the actual building (including the prayer hall) and the minaret.

During the history, these buildings, have suffered severe damages, which has led to destruction of their components. Thus, following the environmental phenomena actions such us: extreme weather phenomena, salt-rich marine waters, groundwater, uneven settlements, landslides, seismic action, but also anthropogenic phenomena caused by wars, other constructions near these building that damage the soil where the foundation of the mosques is located, the behaviours of the resistance structures are different according to the type of these buildings.

The mosques have several values: spiritual, economic and special social which are defined as follows:

- $\quad$ spiritual value - is the place where Muslim believers come and pray;

- economic value - these are old buildings, with special history and architecture, which attract visitors to the areas where they are located.

- social value - is the place where social events often take place.

In this paper we have chosen as a case study three special mosques, both in terms of architecture and history: the "Esmahan Sultan" Mosque in Mangalia, the "Mahmud Yazigi" 
Mosque in Isaccea, and the "Carol I" Mosque in Constanta. They were chosen in this study because they come from different periods, and the materials used for building of these mosques are different.

\section{EXPERIMENT DESCRIPTION}

In this study we developed an analysis method, as clear and accurate as possible of each mosque to determine:

- building technique;

- conservation technique;

- their history.

So, we followed these steps:

- the documentation research;

- the on-site research;

- the results quantification after these two stages.

In the first stage we carried out a series of investigations, by researching studies that have been done on the mosques such as recent technical expertise, old documents and specialized books, thus we obtained data about natural events that led to the degradation of these mosques and data about the way they were built.

The second stage was realised by performing on-site measurements and analyses, to observe the stage at which they occur and wether the measures that have been taken over time are correct.

\section{RESULTS - REMARKS}

\section{1. "Esmahan Sultan” Mosque}

It is a construction built in 1573, located in Mangalia city, in a protected area of historical value.

The construction has the following general characteristics:

- the foundations of the mosque and the minaret are located about $1.50 \mathrm{~m}$ from the ground level;

- the characteristics of the location, according to Romanian norm P100-1/2013: corner period $\mathrm{Tc}=0,7 \mathrm{sec}$. and ground acceleration $\mathrm{ag}=0,2 \mathrm{~g}$;

- dimensions: 23.9x12.1 (including the veranda);

- built area: 312 sqm (including veranda and minaret);

- usable area :193 sqm (excluding the veranda) (Figures 1, 3).

The structure of the mosque is made of masonry of blocks of light-yellow, whiteyellow limestone, which is a stone specific to the area. The masonry structure was made by Turkish stonemasons, according to the techniques of that time; the limestones are connected to each other by steel camps cast in place in holes made of stone and lime mortar, sand and clay in the masonry joints.

The plan shape of the mosque is rectangular and includes on about $70 \%$ of the surface one floor. The thickness of the walls varies, in the southern part the thickness of the wall is $1.05 \mathrm{~m}$, while in the other walls the thickness is about $85 \mathrm{~cm}$. The elevation to which the masonry of the mosque rises is $+5.2 \mathrm{~m}$. There are 14 windows, located on all 4 sides of the building. 




Fig. 1 „Esmahan Sultan” Mosque plan

The structure on the area where the prayer hall is divided on two levels is made of wooden pillars and marble columns, over which are located a wooden floor that is $2.62 \mathrm{~m}$ from the floor of the mosque. The ceiling of the mosque and the roof are made of wood, and the outside part of the roof is made of awnings. The elevation at which the ridge of the building is located is $7.37 \mathrm{~m}$ (Figure 2).

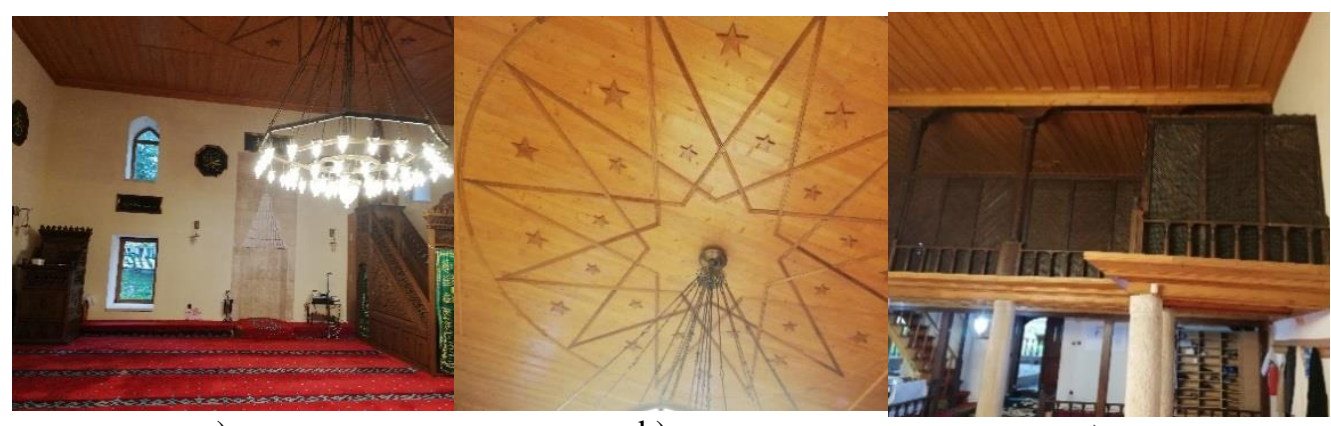

a)

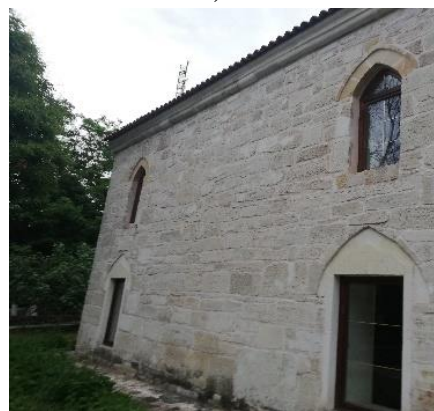

d) b)

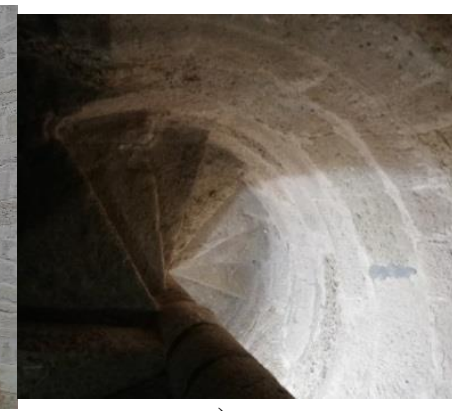

e) c)

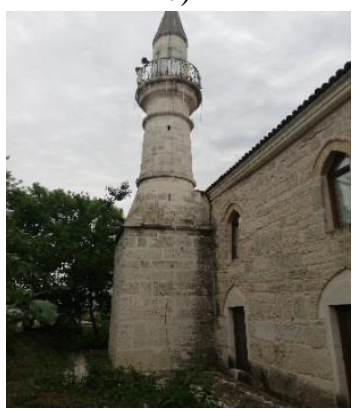

f)

Fig. 2 The mosque finishes a) the mosque inside, b) the mosque ceiling, c) the second floor, d) the mosque outside, e) the minaret inside, $f$ ) the minaret outside 
On the outside part the masonry is apparent and on the inside part the walls are plastered and painted. Also inside, the floor is made of hexagonal ceramic bricks, and for the second floor on down part are using the wood. The ceiling is made of plank, with a central decoration.

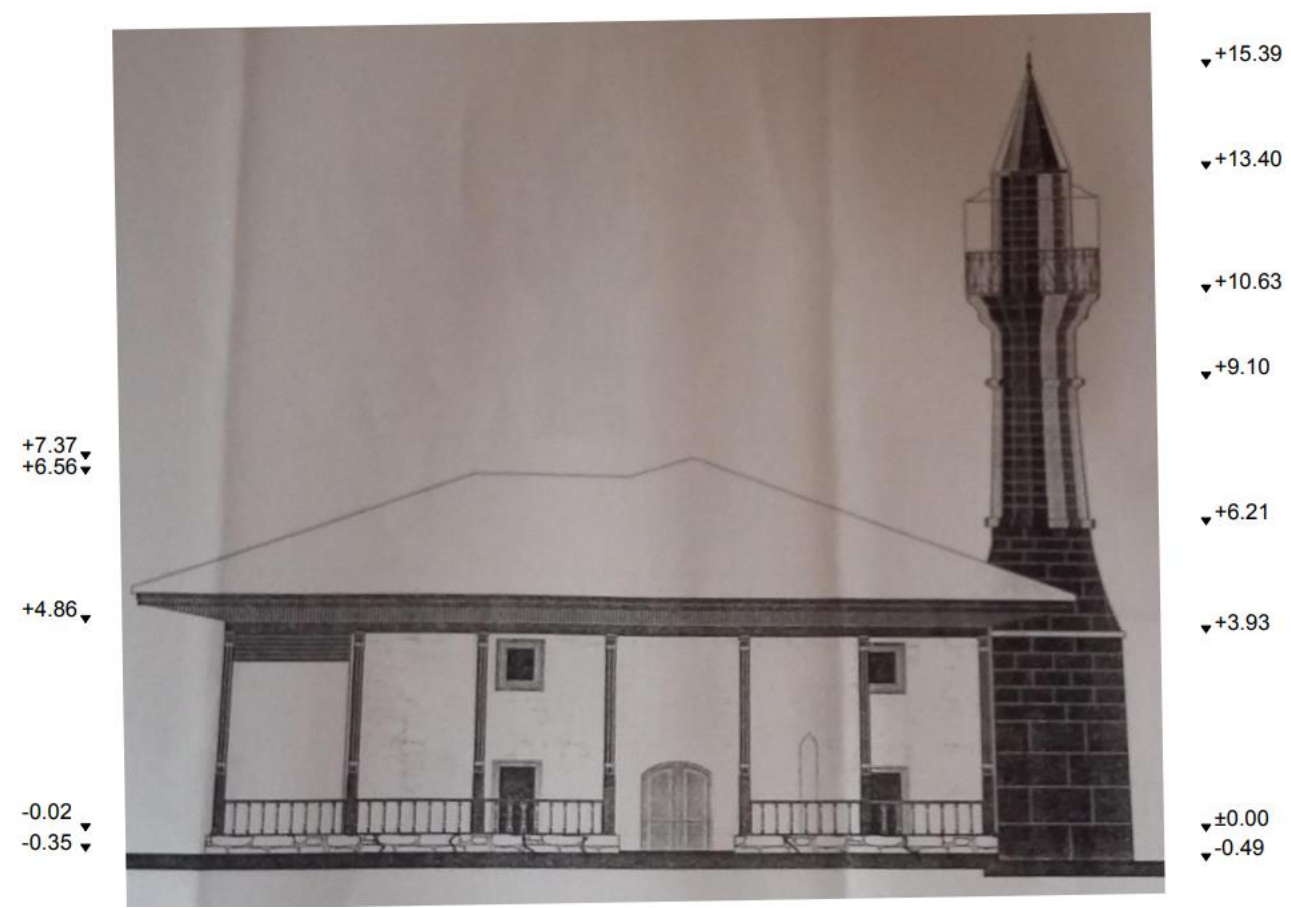

Fig. 3 „Esmahan Sultan” Mosque (side view)

The minaret of the mosque is made, like the mosque itself, of limestone masonry connected with lime-sand mortar, but also with steel camps cast in place. The size of the minaret walls decreases from the base to the top. On the inside there is a spiral staircase that leads to the balcony and is also made of stone. The roof is made of wood and the roof is made of tin. The plan shape of the minaret is square, and from a height of $+4.00 \mathrm{~m}$ it becomes truncated cone shape (Fig.ures 4, 5).

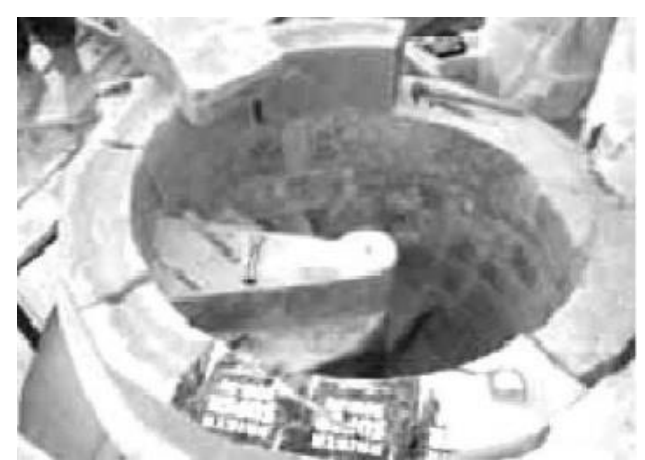

Fig. 4 Minaret construction technique 

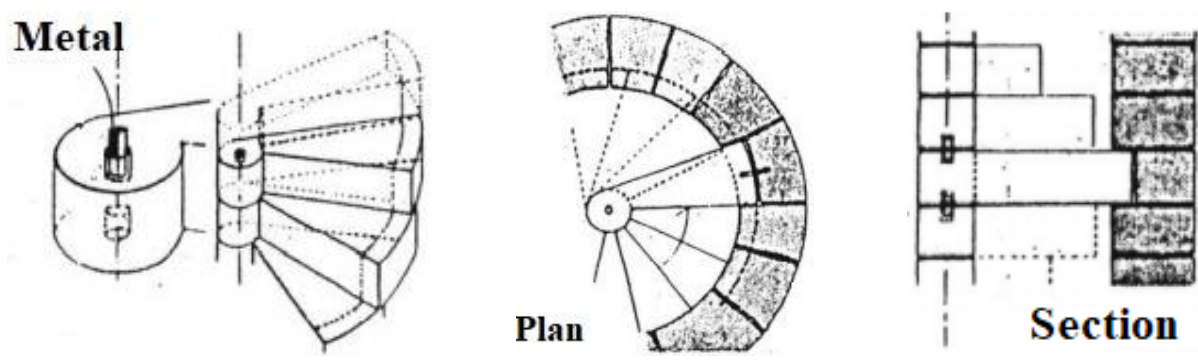

Fig. 5 Minaret construction technique

\section{2. "Mahmud Yazigi" Mosque}

The Isaccea mosque was built in 1771, and over time it was restored in 1886 and 1916.

The construction has the following general characteristics:

- the foundations of the mosque and the minaret are located at about $1.70 \mathrm{~m}$ from the ground level;

- the characteristics of the location, according to Romanian norm P100-1/2013: corner period $\mathrm{Tc}=0,7 \mathrm{sec}$. and ground acceleration $\mathrm{ag}=0,25 \mathrm{~g}$;

- dimensions: $13.75 \times 9.74$ (including the veranda);

- built area: 156 sqm (including veranda and minaret);

- usable area :126sqm (excluding the veranda) (Figure 6).

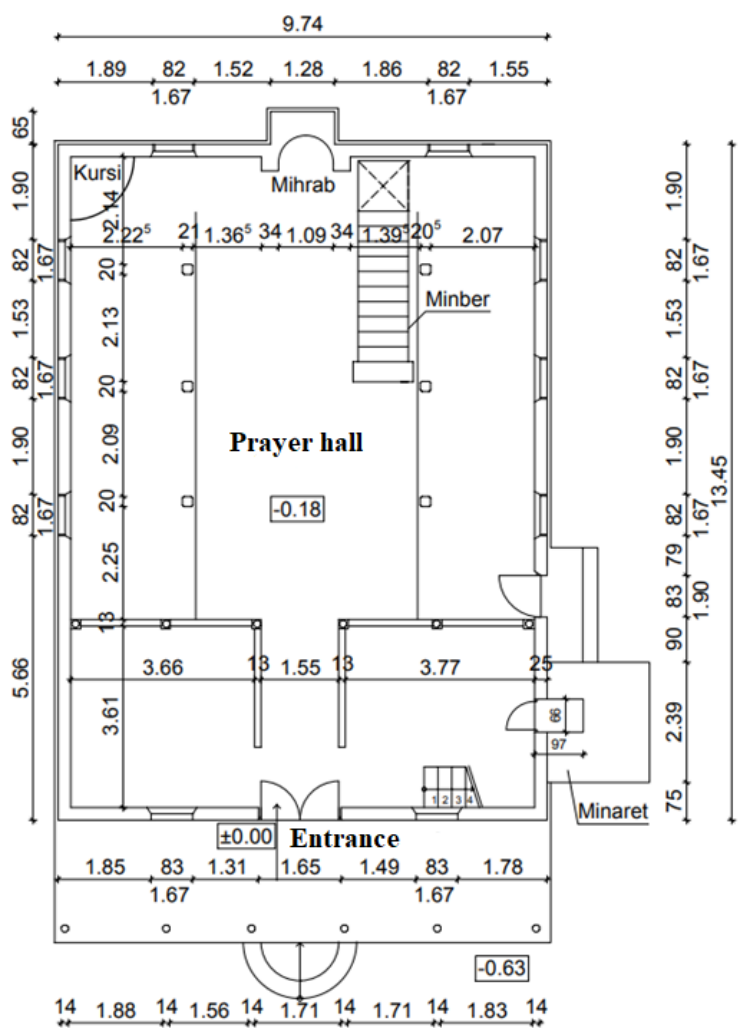

Fig. 6 "Mahmud Yazigi" Mosque plan 


\section{sciendo}

94 Ovidius University Annals Series: Civil Engineering, Year 23, 2021

The building is made of brick masonry and structure with beams, pilars and solid wood braces. Both inside and outside the walls are plastered, and for a proper connection between the plaster and the structure of the building, wire mesh was used. The thickness of the walls is $20 \mathrm{~cm}$, and the floor of the building is also made of wood (Figures 7, 8).
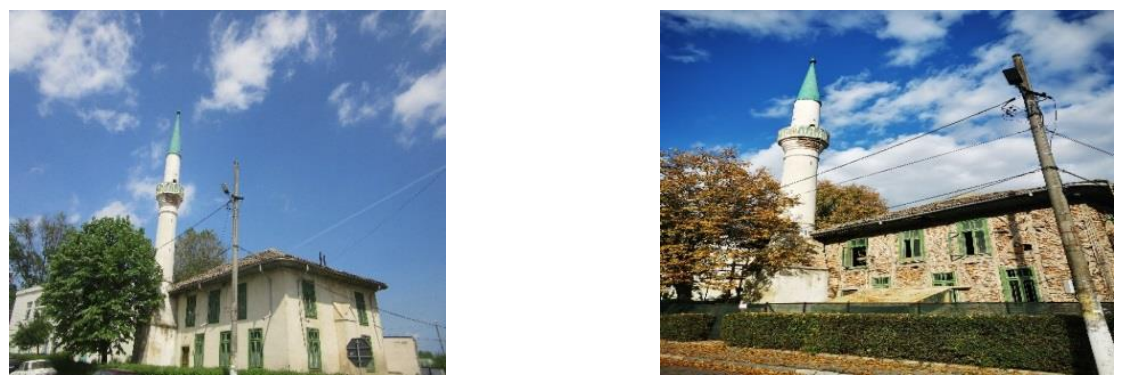

Fig. 7 Mosque outside part

The ceiling and roof of the mosque are made of wood, and the outside of roof is made of awnings. (Fig. 8).

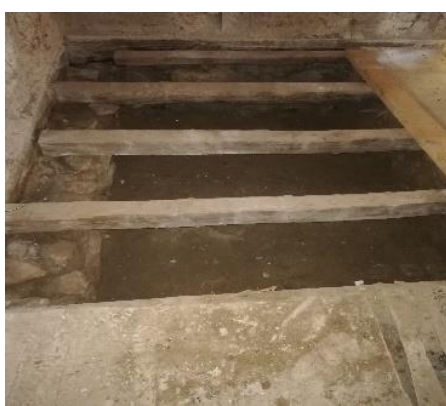

Fig.8 Wooden floor

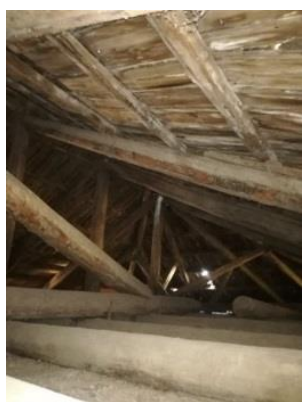

Fig.8 The mosque roof

The mosque minaret is attached to the actual construction and is made of brick and stone masonry, and the spiral staircase is made of prefabricated wooden elements. At its base, the shape of the minaret is rectangular, and from the upper part of the mosque it acquires the truncated cone shape, and the thickness of the wall decreases from the base to the top. Both inside and outside the walls of the minaret are plastered. The roof of the minaret is made of wood, and the upper part of roof is made of tin (Figure 9).

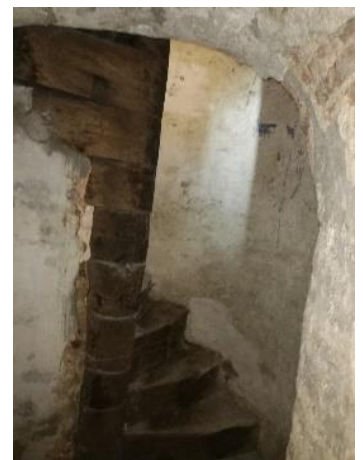

Fig. 9 Minaret inside 


\section{3. "Carol I" Mosque}

The „Carol I" Mosque was built between 1910-1913, by the Romanian state, during the reign of King Carol I, which is why it was named after the king. Before its construction, there was another, older mosque, named Mahmudia, and it was demolished.

The construction has the following general characteristics:

- the characteristics of the location, according to Romanian norm P100-1/2013: corner period $\mathrm{Tc}=0,7 \mathrm{sec}$. and ground acceleration ag $=0,20 \mathrm{~g}$;

- dimensions: 30x16.50 (including the inner courtyard);

- built area: 833sqm (including the inner courtyard and basement);

- usable area :254sqm (includes only the prayer room) (Figure 10).

The structure of the mosque is made of different materials as follows:

- on foundations and basement walls - stone masonry;

- on the walls of the superstructure - brick masonry;

- at the dome and slabs - reinforced concrete;

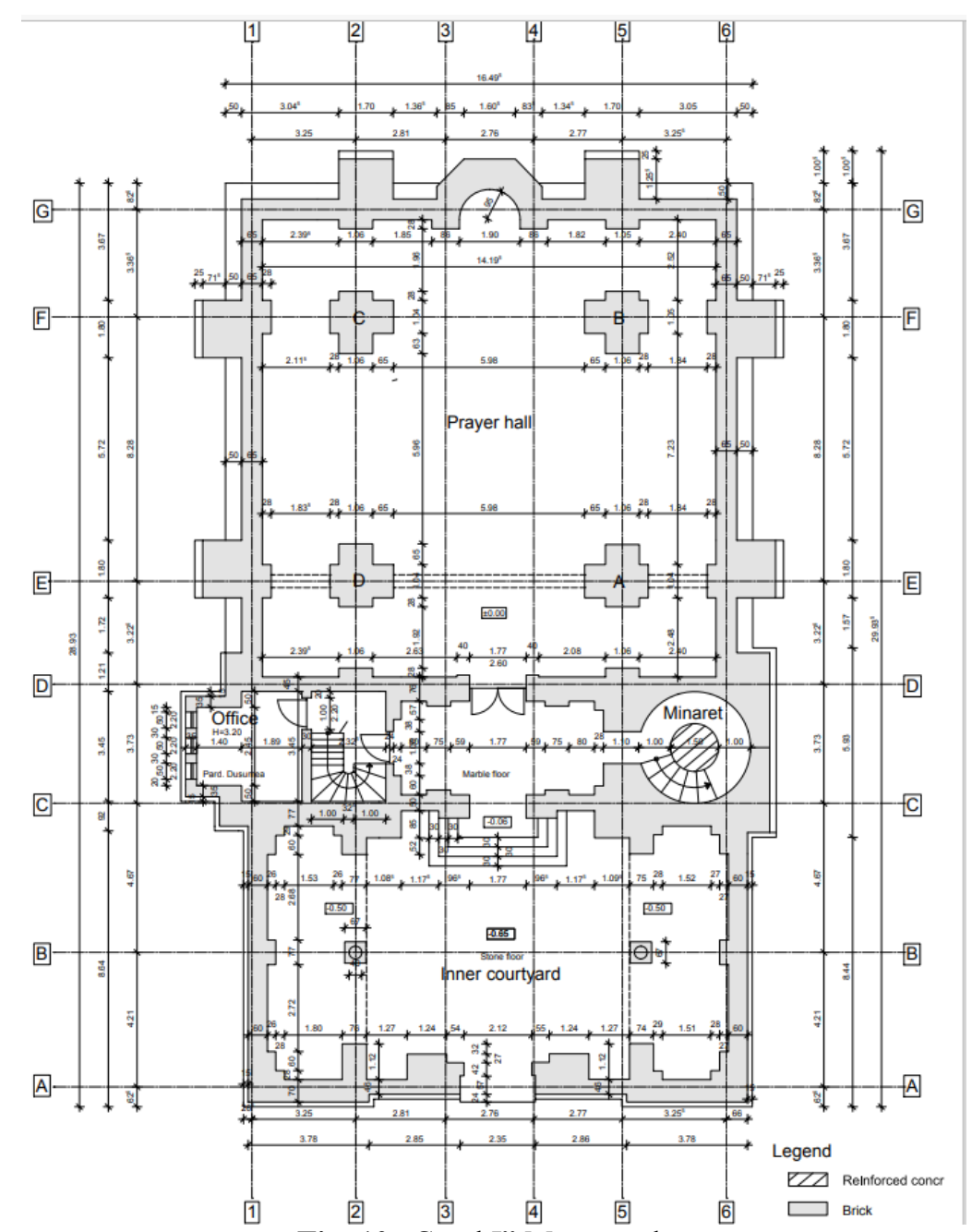

Fig. 10 „Carol I” Mosque plan 


\section{sciendo}

96 Ovidius University Annals Series: Civil Engineering, Year 23, 2021

One of the distinctive elements of the royal mosque is the minaret over $40 \mathrm{~m}$ high. Designed as a tower, the minaret has 140 spiral steps inside. The dimensions of the steps are between $22-44 \mathrm{~cm}$ long and $17 \mathrm{~cm}$ high, respectively. The construction is made of reinforced concrete and according to the information and studies performed the concrete class is C6/8. The minaret has a cylindrical shape based on a diameter of $3.90 \mathrm{~m}$, and at the top the diameter is $2 \mathrm{~m}$. The wall thickness is $20 \mathrm{~cm}$. Inside, in the middle of the minaret, the steps are connected in this system of the minaret with the help of the central pillar, that like the minaret has a cylindrical shape, based on a diameter of $1.50 \mathrm{~m}$, and at the top 0.6 $\mathrm{m}$. the height of central pillar is about $27 \mathrm{~m}$. (Figure 11).

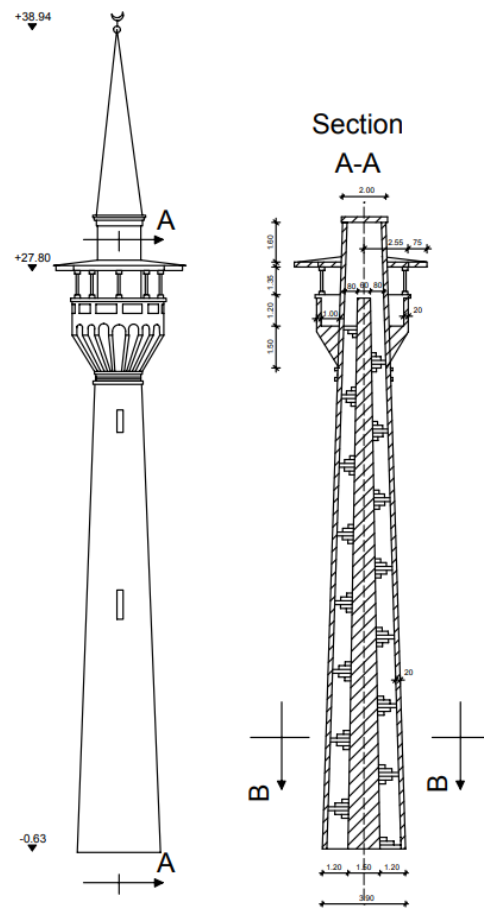

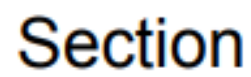

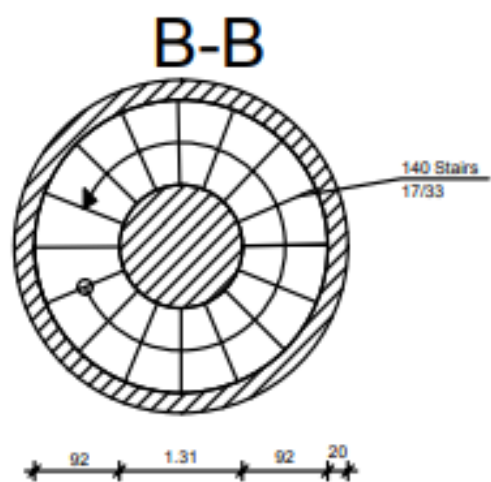

Fig.11 „Carol I” mosque minaret

\section{CONCLUSION}

These three mosques are similar in the type of walls: masonry, but differ in the material used, namely: the brick for the mosque in Isaccea and Constanta, and the limestone for the mosque in Mangalia.

These constructions were built in different periods, they are made of materials specific to those periods but also according to the technologies of that time.

Regarding to the first two mosques we observed, even if the building years, the materials used, and the technologies adopted are different, the elements of the inside remain the same and the structural shapes, namely:

- $\quad$ the shape of the construction is rectangular;

- the minaret at the base has a square or rectangular shape at the base, and from the upper levels their shape becomes truncated cone shape. 
But, at the "Carol I" Mosque we notice that the plan is still rectangular, but the wooden roof is replaced with another element, namely the dome which is made of reinforced concrete - in fact among the first applications of reinforced concrete in Romania.

This program is immediately applicable and is useful in designing, building and operating of heating systems consisting of solar collectors and hot water storage tank and the solar collector coupled with an inbuilt heat exchanger in the storage tank, making simulations and seeing how the parameters mentioned above evolved over the simulation time period and for the specific conditions in each case.

\section{REFERENCES}

[1] Ana Maria Gramescu, Mihaela Pericleanu, Suliman Sever, History of construction science and technology expression of Muslim civilization in the Dobrogea area, Ed. MATRIX ROM, Bucharest 2018

[2] List of historical monuments - Constanta County, Department of Culture

[3] Acuarela Hector de Bearn 1828 from Sourvenir d'une campagne en Turque en 1828 nouvellment construite, Academy Library

[4] Andresoiu B., Baracescu C., Maxim M., Nicolau S., Bonciocat S., Artenie C.(2012), Mosques. Minarets in the sky of Dobrogea, Ed. Igloo Patrimoniu

[5] Technical expertise for the consolidation, restoration and rehabilitation of Hunkiar Mosque bvd. Tomis, no. 41, Constanta; No. Pr. 1354a/2017;

[6] Technical expertise for the consolidation, restoration and rehabilitation of Esmahan Sultan Mosque, No. Pr. 10/2006

[7] Methodology regarding the program for follow-up of the behavior of constructions from the point of view of the functional requirements, Indicative MP031-03

[8] Turks and Tatars in Romania, "Muslim worship places in Romania - Dobrogea" The muftiat of the Muslim cult in Romania

[9] Methodology for risk assessment and intervention proposals necessary for the structures of historical monuments constructions within their restoration works, Indicative M.P.025-04

[10] Design code for masonry structures, Indicative CR 6

\section{Note:}

Sever Suliman - PhD, Ovidius University of Constanta, Institute of Doctoral Studies, Bd. Mamaia nr. 124, 900356-Constanta, Romania (corresponding author to provide e-mail: eusever@ yahoo.com)

Ana Maria Gramescu - Ovidius University of Constanta, Institute of Doctoral Studies, Bd. Mamaia nr. 124, 900356-Constanta, Romania (e-mail: am_gramescu@yahoo.com) 